\title{
Construction of the Teaching Model of Second Classroom of Translation Based on Network Platform
}

\author{
Fei Liu \\ School of Foreign Languages, Shanxi Datong University, Datong, China \\ Email: feiexertion@163.com
}

How to cite this paper: Liu, F. (2019) Construction of the Teaching Model of Second Classroom of Translation Based on Network Platform. Open Journal of Social Sciences, 7, 167-177. https://doi.org/10.4236/jss.2019.72014

Received: January 28, 2019

Accepted: February 17, 2019

Published: February 20, 2019

Copyright $\odot 2019$ by author(s) and Scientific Research Publishing Inc. This work is licensed under the Creative Commons Attribution International License (CC BY 4.0).

http://creativecommons.org/licenses/by/4.0/

\section{c) (i) Open Access}

\begin{abstract}
In order to further deepen the reform of college English teaching and improve the translation level of students, a teaching model of second classroom of translation based on network platform was proposed. The second classroom activities include audio visual group activities, conversational group activities, reading group activities, writing group activities, teaching group activities, research innovation and translation team activities. The organization and evaluation of the second classroom activities include the second classroom annual work plan, student scope, teacher and student assessment, and work summary. The results show that the second classroom fully mobilizes the initiative and enthusiasm of students to learn language and create a good learning environment. The translation level of students is improved, and they become applied talents. Therefore, the second classroom teaching mode can improve students' enthusiasm for college English courses, promote the exchange of classroom teaching, and improve the teaching effect of college English courses. In addition, students achieve better results in the second classroom mode than in the traditional mode. At the same time, the second classroom teaching mode helps students to improve their self-learning ability and effectively promote personalized learning.
\end{abstract}

\section{Keywords}

Network Platform, Translation, Second Classroom, Teaching Model

\section{Introduction}

In the 21 st century, informatization and globalization continue to impact the education sector. The popularity of the Internet and the application of computer technology in education have opened up new possibilities for the reform of tra- 
ditional teaching models. The second classroom teaching model came into being in this context. This model combines advanced network information technology with innovative teaching concepts. The traditional teaching model has been changed, which has aroused widespread concern in the global education community. This kind of teaching model originated in the United States has gained high recognition among American teachers and students through the in-depth research and promotion of researchers and educators. Chinese scholars have also begun research and application of the second classroom. At present, the extensive application of mature network information technology and the support of the Ministry of Education policy provide a good opportunity for the promotion and application of second classroom in China [1].

College English course is a public basic course in higher education in China. The quality of college English teaching and students' learning effect influence the development of other teaching activities. College English learning is not only of great significance to broaden students' international vision, but also the key to learn professional knowledge and improve their competitiveness in employment. In the context of reducing the number of hours taught in the classroom, if students do not take the initiative to practice English and practice outside the classroom, it is impossible to master and apply the knowledge acquired in a limited time, and their academic performance will be difficult to improve. According to the characteristics of language learning, students can closely link classroom learning with daily practice to learn English [2]. Translation is a very practical subject. Limited classroom teaching is not conducive to mobilizing and exerting the enthusiasm of students' independent learning. It is difficult to improve students' ability to use language comprehensively in violation of the law of language learning [3]. The language environment and atmosphere provide students with the conditions to use the language, which is the main purpose of the second classroom. This paper is based on the structure of introduction, literature review, case discussion, results and discussions, conclusions and prospects. The second classroom teaching mode based on network is studied.

\section{Literature Review}

The concept of second classroom was first raised in American colleges and universities. In 2016, Heyborne and Perrett proposed the concept of peer instruction. Computer-aided teaching enables teachers to give guidance in the learning process instead of blindly teaching in class [4]. In 2016, Wong pointed out that second classroom was only the beginning of computers as a necessary part of education [5]. In 2016, Alzubaidi et al. believed that second classroom increased the interaction and contact time between students and teachers. It is a teaching model that combines direct explanation and constructivist learning [6]. In 2016, Unruh et al. established the Khan Academy on the basis of the second classroom. Students can watch the teaching videos at home according to their own schedule. In the classroom, under the guidance of teachers, they can discuss 
problems with students and complete the expansion of knowledge [7]. In 2016, Goh and Sandars recorded their lectures in video format and posted them online to help students who were absent from class, which was welcomed by students and parents [8]. In 2016, in order to enable more teachers and classmates to understand the second classroom teaching mode, Cornell et al. held a second classroom open day at Woodland Park High School. The teaching method of the second classroom and the learning methods of the students are presented. This practice has promoted the second classroom teaching model [9]. In 2017, Liu and Chen pointed out that each flipping class is unique. At the same time, four key factors affecting the flipping classroom are proposed: the flexibility of the learning environment, the cultural change in learning, the selected teaching content and the professionalism of the teacher [10].

In recent years, with the acceleration of globalization and the arrival of the era of data, the second classroom teaching model has also received great attention in China. In 2017, Hang et al. believed that the proposal of second classroom concept was mainly relative to the traditional teaching model [11]. In 2017, Lax et al. pointed out that students use the terminal devices such as computers, mobile phones, and notebooks to watch the teacher's lecture videos, browse related learning materials, and record problems in the learning process [12]. In 2018, Yan et al. pointed out that the information transfer of the second classroom was mainly placed under the class and completed by the students themselves. The process of knowledge internalization is placed on the classroom, and the learning tasks are completed through collaboration between students and between teachers and students [13]. In 2018, Minuti et al. discussed the meaning of the flipping classroom in three aspects. The first is the subversion of the teaching process. The second is the transformation of the roles of teachers and students. The third is the improvement of the learner's thinking quality [14]. In 2018, Owolabi et al. proposed the practice of teaching and learning in the second mode. The school's teaching quality test data showed that it achieved good results. Because through the second classroom, students can adjust the learning rhythm according to their needs. In the classroom, students are always in the state of thinking, analysis and exploration, and constantly improve the ability to analyze problems and solve problems [15]. Researchers combine their work and their own understanding of the second classroom. Different attempts have been made at the level of student education. In order to help other researchers further improve the effectiveness of the second classroom teaching. This paper summarizes the process of the experiment.

\section{Case Discussion}

Second classroom, simply speaking, is a kind of learning from extracurricular learning, activities, practice to obtain knowledge and skills, so as to achieve the comprehensive quality of college students a way of growth. The learning of the second classroom depends on the first class and is not limited to the first class. It 
has a wide range of learning. The form is lively and colorful. It is not limited to knowledge in books. More importantly, the development of the overall quality of students is emphasized (Figure 1).

English is taught and learned as a foreign language, and students lack the real language environment of native English. Most students learn English mainly from classes. However, due to the limited class hours and application opportunities, students do not have enough time and opportunities to learn English, and it is difficult for them to fully understand and apply language rules from a large number of language practices. Only when students master the basic knowledge and the necessary grammar rules, rationally understand them and combine them with language practice, can they master and correctly use English. Therefore, how to teach English grammar effectively is a long way to go. Although the origin of translation studies is relatively late compared with foreign specialized language studies, many foreign language education researchers have been engaged in the reform of translation teaching research in modern times. In terms of teaching content, it originates from textbooks and is not limited to textbooks; it does not need examinations, but it is also an indispensable part of quality education. Formally, it is lively and colorful. Its learning space is very broad: it can be carried out in the classroom or in the playground; it can be carried out in schools, society and family.

\section{Results and Discussion}

\subsection{The Relation between the First Classroom and the Second Classroom}

Although it is good for the country and the people that colleges and universities cultivate talents, a series of problems are caused by the difficulty in finding jobs

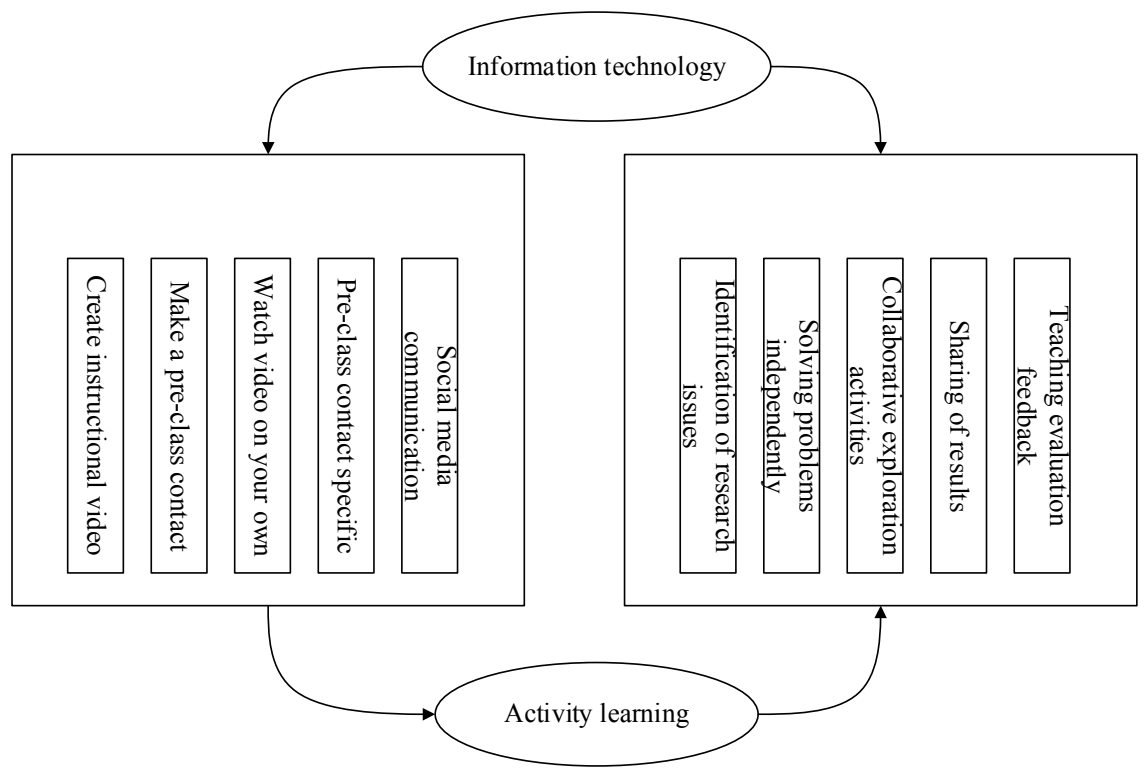

Figure 1. An exploration of the second class. 
for college students. Talent cultivation and employment work are in trouble. Enterprises blame students for their practical application ability. Students and their parents consider the school to be responsible. The quality of students is not as good as one year. In terms of the training of students in colleges and universities, in the past, the university was oriented to the lack of scientific research personnel and the pursuit of elite education. The first class of mass education only focuses on the cultivation of professional knowledge and scientific research ability, which obviously cannot meet the talent standards of employers. The task of education cannot be completed, and the win-win of all stakeholders is realized.

Under the goal of "win-win" college education, second classroom paid attention to the professional requirements and vocational requirements. The quality education of students will be expanded from the original only limited to ideological education and interest guidance to professional self-development. The professional quality of college students is improved. From the behavioral and linguistic perspectives, the relationship between the first classroom and second classroom was studied. Taking second classroom activity in translation as an example, the complementary relationship between the first classroom and the second classroom was fully utilized, which was the best way to realize the process of English language learning and its practical application. Relationship between the first classroom and the second classroom is shown in Figure 2.

\subsection{The Necessity of the Construction of the Second Classroom of Translation}

For a long time, the teaching focus and teaching methods of secondary school English have been concentrated in the classroom. English classroom teaching is characterized by teaching materials. Classroom teaching, as the most basic and universal teaching form, has its extensive advantages. However, because of the traditional English teaching method, students rely too much on teachers and lack initiative and independence in learning. However, teachers pay too much

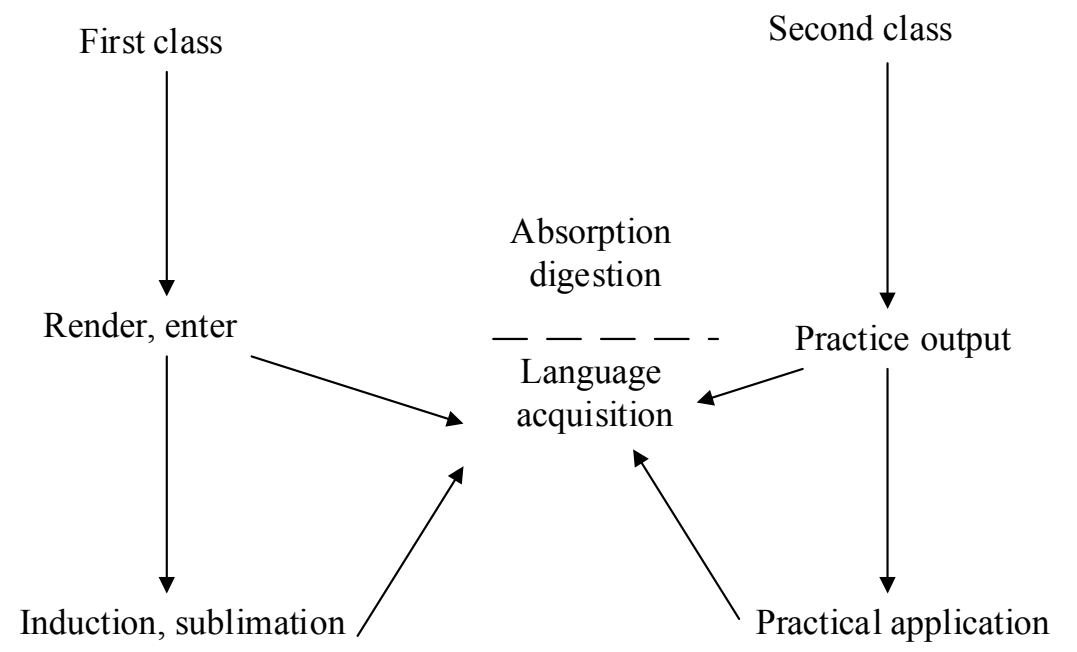

Figure 2. Relationship between the first classroom and the second classroom. 
attention to the teaching of language knowledge points and neglect the cultivation of students' abilities and learning methods. Therefore, there are actually many drawbacks due to the limitations of time and conditions. In the classroom, teachers cannot take care of the individual differences of each student. It is difficult to guide students in accordance with their aptitude. Students are subordinate to teachers in the process of classroom teaching. The initiative and enthusiasm of English learning have not been fully realized. Students have fewer practical opportunities, and their ability to create is difficult to develop. Theory cannot be applied to practice. With the globalization of the economy, translation talent is very important. Therefore, social development and economic construction put forward higher requirements for English teaching. The new teaching model should develop in the direction of individualized and active learning. Schools must create conditions for students to learn English regardless of time, place, and environment. The effective development of the second classroom is based on the above requirements, to build a scientific, systematic and complete learning platform for students.

\subsection{Construction of the Assessment System of the Second Classroom}

The second classroom quality training system for college students is a complete and independent operation system. Combined with the characteristics of the second classroom of college students, they are generally divided into student performance appraisal system, quality appraisal system and operation system. The operating system is the core and basic part of the whole system. It was the organization and development system of second classroom in colleges and universities, including all the contents of the planning and implementation of various activities. Second classroom comprehensive quality assessment system for college students mainly reflects the results of the operation system for college students. The performance of students participating in the second classroom was comprehensively evaluated and recorded. The effective regulation of the second classroom training system must also strengthen the management of human resources in the second classroom. The establishment of teachers' performance assessment system was to establish a standardized and orderly management system integrating supervision, assessment and reward as a whole to ensure the smooth development of the work in second classroom. Under the common restriction of hard environment and soft environment, the three systems have formed a complete assessment and evaluation system (Figure 3 ).

The quality training system of the second classroom of college students is mainly constructed through the five modules of science and technology practice innovation ability, education academic education, ideological and moral education, sports psychology education and humanity quality education. The ability of practice and innovation is mainly to train students from the innovative thinking, practical ability and way of thinking. Science and technology academics are 


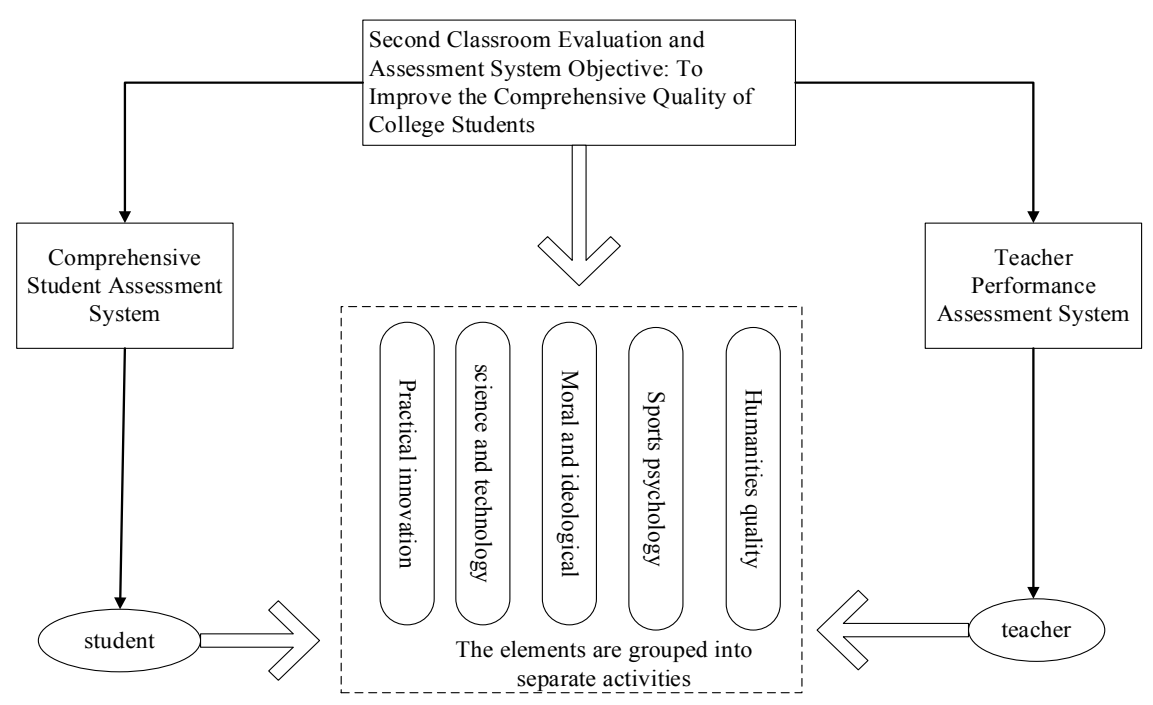

Figure 3. Second classroom evaluation system.

mainly cultivated from the perspective of student article publication, participation in scientific research, foreign language proficiency, computer and professional technology. Ideological and moral education is mainly cultivated from the perspective of students' legal concept, moral behavior and political literacy. Physical education is mainly to strengthen students' physical and mental training from the aspects of students' psychological quality and physical quality. The humanities quality is mainly cultivated in terms of improving students' artistic accomplishment, knowledge accumulation and comprehensive application ability of knowledge. According to the above-mentioned aspects of education and teaching content, the actual situation of different colleges, different majors and different grades of students, the corresponding training program was formulated. Through the innovation and science and technology academic, moral quality and ideological and political, social work and community activities, physical and mental development and stylistic art and other types of characteristic theme activities, the basic framework for quality education in colleges and universities is constructed. In the second classroom, students' subjective initiative is the key factor of learning effect. Through rules to guide students, help students find their interests in the second class, and find their own deficiencies in English learning in the attempt. Gradually try to improve their English ability by checking omissions and filling in vacancies.

\subsection{An Experimental Study on Creating the Second Classroom of Translation}

Experimental subject: On the basis of voluntary registration, 123 students majoring in English (business and trade) in grade 2015 of the school of foreign languages were tested in March 2016. A total of 60 students who are interested in translation-related industries and have strong translation skills are selected as experimental subjects. 
Experimental method: In June 2016, the translation ability of the subjects was comprehensively evaluated for the first time. The number is used to retain the assessment paper and requires the translator to do a written self-evaluation. Sixty students were randomly divided into two groups. Group A was the experimental group and group B was the control group. In the 18 weeks after the beginning of the new semester in September, students in group A had two classes of second classroom learning and discussion every week. After class, about 5 hours of computer learning will be arranged for students to complete homework, group discussion, translation mutual evaluation and other activities. The translators of the company implement remote monitoring of the whole process to assist teaching. The problems encountered during this process were collected. The company selects excellent translators from the front line to answer questions every week through the network. Enterprises select trade and economic translation cases in advance in order from easy to difficult for teaching use. Cases include business contracts, company profiles, business letters, emails, business promotion plans, product introductions, advertising translation and other types. The teaching method is adjusted in time according to the students' reaction. Students in group B received traditional translation classes. After class, students have about 7 hours of independent computer learning.

Experimental content detection: After the 18-week translation training, the subject was subjected to a second evaluation using a translation material with the same difficulty factor (using a web platform). The number is saved and the translator makes a written self-evaluation (Table 1).

The average score of the experimental class was 94.22, and the average of the control class was 89.97. The overall average score of the experimental class was higher than that of the control class. The highest score for both classes is 100 points. However, the minimum score for the experimental class is 84 , which is higher than the lowest score of 80 for the control class. This shows that compared with the traditional teacher-led teaching mode, the second teaching mode has a better effect on promoting students' performance.

At the same time, the test scores of the two classes were tested by SPSS statistical software using independent sample $t$ test. The test results are shown in $\mathrm{Ta}$ ble 2 .

As can be seen from the analysis, the sig value is $0.122>0.05$. This shows that the original hypothesis is accepted and the variance is homogeneous. There were no significant differences between the two samples. The test results of the experimental group and the control group were similar and comparable. When the

Table 1. Test scores of experimental group and control group.

\begin{tabular}{cccccccc}
\hline & $\begin{array}{c}\text { Teams and } \\
\text { groups }\end{array}$ & $\begin{array}{c}\text { Number of } \\
\text { people tested }\end{array}$ & $\begin{array}{c}\text { Mean } \\
\text { value }\end{array}$ & Maximum & $\begin{array}{c}\text { Minimal } \\
\text { value }\end{array}$ & $\begin{array}{c}\text { Standard Standard error } \\
\text { deviation }\end{array}$ & of mean \\
\hline Mark & $\begin{array}{c}\text { Control group } \\
\text { Experimental } \\
\text { group }\end{array}$ & 30 & 89.97 & 100 & 80 & 5.833 & 0.972 \\
& 30 & 94.22 & 100 & 84 & 4.811 & 0.802 \\
\hline
\end{tabular}


Table 2. T test of independent sample of test results in experimental group and control group.

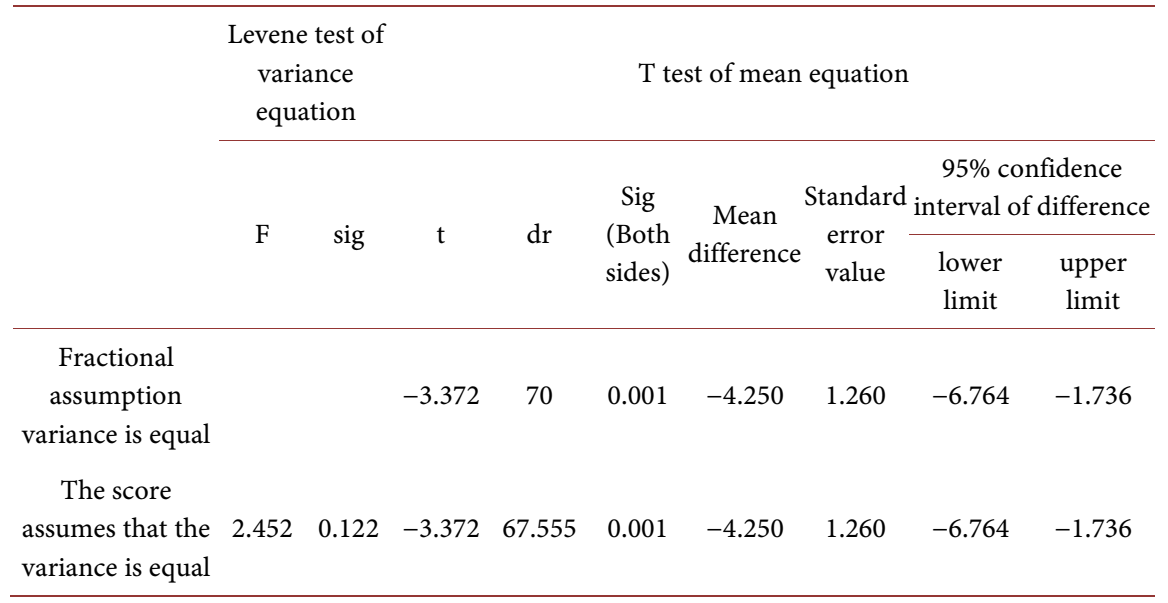

$\mathrm{P}$ value of the two classes was $0.001<0.05$, the original hypothesis was rejected, indicating that the test results of the experimental group and the control group were significantly different. It was evident that the influence of second classroom teaching mode and traditional teacher-centered teaching mode on students' test results was significantly different. In the second classroom teaching mode, students achieved better results, so the teaching effect of this teaching mode was better than that of traditional teaching-centered teaching mode.

\section{Conclusions}

Second classroom is more than an extension of the first classroom. The content of teaching has been enriched, the scope of teaching activities has been expanded, and the venues have been changed. It is an independent educational platform. In essence, the first class puts forward the universal requirements for talent cultivation, and the common problems in talent cultivation should be solved. Second classroom solves the particularity problem in talent training. Different students have different foundations and learning abilities, so it is inevitable that there will be a certain gap through classroom teaching alone. The second class can make up for this problem, students through extracurricular activities. Find out and understand their own shortcomings, so as to carry out targeted learning and training, make up for the shortcomings of classroom education.

With the development of modern information technology, modern educational technology based on computer and network technology provides a new direction for the improvement of teaching mode. The second classroom teaching mode combines computer-aided teaching with network platform technology, which makes up for the shortcomings of the traditional teaching model. College English curriculum reform should make full use of modern information technology, especially network technology. To some extent, teaching and learning can be independent of time and place, and the formation of personalized learn- 
ing methods and the development of students' independent learning ability can be promoted. Second classroom teaching mode was applied to college English teaching, which was an effective attempt for the new teaching mode. This provides a reference for the further application of the second classroom teaching mode to the classroom. There are still some limitations in this study. With the development of technology, more and more high-tech products have been popularized. Students can develop interest in entertainment and learn in play by using updated equipment. The research in this paper does not involve the application of equipment, which makes the research have some limitations.

\section{Acknowledgements}

The project was supported by Teaching Reform Project of Colleges and Universities in Shanxi Province (Project No. J2016087); Major Teaching Reform Project of Shanxi Datong University (Project No. XJG2015110).

\section{Conflicts of Interest}

The author declares no conflicts of interest regarding the publication of this paper.

\section{References}

[1] Mountford, S.J., Zheng, Z., Sundaram, K., et al. (2015) Class II but Not Second Class-Prospects for the Development of Class II PI3K Inhibitors. ACS Medicinal Chemistry Letters, 6, 3-6. https://doi.org/10.1021/ml500354e

[2] Heidarkhani, S., Ferrara, M. and Salari, A. (2015) Infinitely Many Periodic Solutions for a Class of Perturbed Second-Order Differential Equations with Impulses. Acta Applicandae Mathematicae, 139, 81-94. https://doi.org/10.1007/s10440-014-9970-4

[3] Koretsky, M.D. (2015) Program-Level Curriculum Reform at Scale: Using Studios to Flip the Classroom. Chemical Engineering Education, 49, 47-57.

[4] Heyborne, W.H. and Perrett, J.J. (2016) To Flip or Not to Flip? Analysis of a Flipped Classroom Pedagogy in a General Biology Course. Journal of College Science Teaching, 45, 31-37. https://doi.org/10.2505/4/jcst16_045_04_31

[5] Wong, Y.L. (2016) Class Differentials in Getting Parental Assistance for Seeking a Second Chance of Getting into University: An Illustration of Community-College Students in Hong Kong. Higher Education, 74, 1-16.

[6] Alzubaidi, E., Aldridge, J.M. and Khine, M.S. (2016) Learning English as a Second Language at the University Level in Jordan: Motivation, Self-Regulation and Learning Environment Perceptions. Learning Environments Research, 19, 133-152. https://doi.org/10.1007/s10984-014-9169-7

[7] Unruh, T., Peters, M.L. and Willis, J. (2016) Flip This Classroom: A Comparative Study. Computers in the Schools, 33, 38-58.

https://doi.org/10.1080/07380569.2016.1139988

[8] Goh, P.S. and Sandars, J. (2016) An Innovative Approach to Digitally Flip the Classroom by Using an Online "Graffiti Wall" with a Blog. Medical Teacher, 38, 1. https://doi.org/10.1080/0142159X.2016.1204433

[9] Cornell, R., Dean, J. and Tomaš, Z. (2016) Up Close and Personal: A Case Study of Three University-Level Second Language Learners' Vocabulary Learning Experi- 
ences. Tesol Journal, 7, 823-846. https://doi.org/10.1002/tesj.247

[10] Liu, L. and Chen, W.X. (2017) Homoclinic Solutions for a Class of Subquadratic Second-Order Hamiltonian Systems. Journal of Yili Normal University, 373, 20-29.

[11] Hang, H., Bo, Z., Yu, C., et al. (2017) Design of Multioctave Bandwidth Power Amplifier Based on Resistive Second-Harmonic Impedance Continuous Class-F. IEEE Microwave \& Wireless Components Letters, 27, 830-832. https://doi.org/10.1109/LMWC.2017.2734764

[12] Lax, N., Morris, J. and Kolber, B.J. (2017) A Partial Flip Classroom Exercise in a Large Introductory General Biology Course Increases Performance at Multiple Levels. Journal of Biological Education, 51, 1-15. https://doi.org/10.1080/00219266.2016.1257503

[13] Yan, J.X., Pan, J. and Wang, H. (2018) Second Language Writing Anxiety and Translation: Performance in a Hong Kong Tertiary Translation Class. Interpreter \& Translator Trainer, 6, 171-194. https://doi.org/10.1080/13556509.2012.10798835

[14] Minuti, A., Sorensen, K., Schwartz, R., et al. (2018) Librarians Flip for Students: Teaching Searching Skills to Medical Students Using a Flipped Classroom Approach. Medical Reference Services Quarterly, 37, 119-131.

https://doi.org/10.1080/02763869.2018.1439184

[15] Owolabi, F.O., Oguntunde, P.E., Adetula, D.T., et al. (2018) Learning Analytics: Data Sets on the Academic Record of Accounting Students in a Nigerian University. Data in Brief, 19, 1614-1619. https://doi.org/10.1016/j.dib.2018.06.078 